A RCHIWA, BIBLIOTEKI

I MUZEA KOŚCIELNE 110 (2018)

https://doi.org/10.31743/abmk.2018.110.04

KS. WŁODZIMIERZ BIELAK* - LUBLIN

\title{
PROBLEM ISTNIENIA PARAFII W STRÓŻY W ARCHIDIAKONACIE ZAWICHOJSKIM W ŚREDNIOWIECZU
}

W literaturze historycznej poświęconej dziejom kościelnym Kraśnika i okolic utarło się przekonanie o istnieniu już co najmniej w czternastym wieku parafii w Stróży ${ }^{1}$. Jak się wydaje pogląd ten najbardziej upowszechnili w historiografii Kazimierz Myśliński ${ }^{2}$ i Henryk Grocholski ${ }^{3}$, do opracowań których wciąż się powraca lub te same tezy powtarza ${ }^{4}$. Przeświadczenie o istnieniu w średniowiecznej Stróży parafii pojawia się również w często cytowanym Słowniku historycznogeograficznym województwa lubelskiego w średniowieczu $u^{5}$. Opinie owe zasadzają się na zapiskach w pochodzących z XIV wieku spisach świętopietrza oraz założeniu, że nie istniała w tym czasie parafia w Kraśniku, dla którego Stróża stanowiła wręcz zaplecze kościelne i duszpasterskie.

W niniejszym artykule zastanowimy się nad zasadnością argumentacji zwolenników istnienia parafii w Stróży już w średniowieczu i postaramy się odpowie-

* Ks. Włodzimierz Bielak - dr hab. historii Kościoła, prof. w Katedrze Historii Kościoła w Starożytności i Średniowieczu, Instytut Historii Kościoła i Patrologii KUL; e-mail: bielakwl@kul.pl

ORCID: 0000-0002-3883-5615

${ }^{1}$ Stróża - wieś położona w powiecie i gminie Kraśnik, siedziba Parafii Rzymskokatolickiej pw. Trójcy Przenajświętszej w archidiecezji lubelskiej.

${ }^{2}$ K. Myśliński, Początki miasta Kraśnika i Urzędowa na tle rozwoju południowej Lubelszczyzny, w: Z dziejów powiatu kraśnickiego, red. Z. Hirsz, Lublin 1963, s. 11- 27; K. Myśliński, Dymitr z Goraja i początki Kraśnika, w: Problemy historii i archiwistyki, red. T. Mencel, Lublin 1986, s. 21-30.

${ }^{3}$ H. Grocholski, Wokót początków Kraśnika, w: Z dziejów powiatu kraśnickiego, red. Z. Hirsz, Lublin 1963, s. 28-32; H. Grocholski, Powstanie archidiakonatu zawichojskiego i jego najstarsze kościoły do połowy XIV w., „Roczniki Humanistyczne”, 13 (1965) z. 2, s. 161.

${ }^{4} \mathrm{~Np}$. E. Zielińska, Kultura intelektualna kanoników regularnych z klasztoru w Kraśniku w latach 1469-1563, Lublin 2002, s. 26; H. Landecka, Kościót parafialny pod wezwaniem Najświętszej Marii Panny w Kraśniku - nowe ustalenia badawcze po I etapie badań - 2008-2009, „Budownictwo i Architektura", 7 (2010) s. 54; S. Gołub, Kościót pw. Wniebowzięcia Najświętszej Marii Panny w Kraśniku - wyniki badań archeologicznych, w: Kościoly, cerkwie i klasztory Lubelszczyzny w świetle badań archeologicznych, red. E. Banasiewicz-Szykuła, Lublin 2013.

${ }^{5}$ Dzieje Lubelszczyzny, red. T. Mencel i in., t. 3: Stownik historyczno-geograficzny województwa lubelskiego w średniowieczu, oprac. S. Kuraś, Lublin 1983, s. 224. 
dzeć na pytanie czy średniowiecznego ośrodka kościelnego w okolicach Kraśnika nie należy jednak szukać poza Stróżą.

We wspomnianej wyżej pracy, Kazimierz Myśliński dochodzi do następujących wniosków: 1) Kraśnik mógł się rozwinąć jako osada targowa przy szlaku handlowym między Polską i Rusią; 2 ) „w XIV wieku Kraśnik nie był siedzibą parafii i że kreowano ją tam nie wcześniej niż w końcu tego stulecia"7; 3) parafia znajdowała się w Stróży, a w Kraśniku istniał już w końcu XIII wieku kościół nieparafialny.

Henryk Grocholski starał się wzmocnić argumentację, wprowadzając do niej nową podstawę źródłową. Dla tego historyka punktem oparcia do uznania Stróży za siedzibę średniowiecznej parafii, oczywiście oprócz wspomnianych spisów świętopietrza, stał się rzekomy dokument wystawiony przez Bolesława Wstydliwego 8 maja 1260 roku dla cystersów z Wąchocka, a opublikowany przez M. Niwińskiego na podstawie siedemnastowiecznego kopiarza ${ }^{9}$, z którego ma wynikać istnienie w Stróży kościoła już w XIII wieku. Dokument ten wspomina mianowicie o dziesięcinie należnej kościołowi w Stróży: „quam decimam tenet ecclesia de Strozy"10.

Spisy świętopietrza z czternastego wieku i dokument Bolesława Wstydliwego są bezpośrednimi świadectwami odnoszącymi się do parafii w Stróży, lecz ich wartość historyczna jest diametralnie różna, o czym za chwilę przyjdzie wspomnieć. W każdym razie zarówno Myśliński, jak Grocholski są zgodni co do faktu funkcjonowania parafii w Stróży już w XIII wieku. Czy rzeczywiście prezentowane źródła dają podstawę do wyciągnięcia tak jednoznacznych wniosków?

Najpierw przyjrzyjmy się argumentacji $\mathrm{H}$. Grocholskiego opartej w głównej mierze na dokumencie Bolesława Wstydliwego. Chodzi przede wszystkim o to, czy dokument ten można uznać za miarodajny i wiarygodny? Wspomnieliśmy, że ów dokument nie jest znany z oryginału, lecz z dość późnych, bo siedemnastowiecznych kopii zawierających dwie redakcje. Ten fakt w poważny sposób osłabia wartość tego świadectwa, bowiem kopie średniowiecznych dokumentów sporządzane w XVII wieku nie wykazują odpowiedniej staranności, ponadto nigdy nie wiemy czy kopista znał oryginał, czy też korzystał ze wcześniejszych odpisów? W tym wypadku nie jest to tak istotne, bowiem sam wydawca wysnuwa poważne zastrzeżenia co do jego autentyczności, jednocześnie zwracając uwagę, że za jedyny autentyczny przywilej Bolesława Wstydliwego dla klasztoru w Wąchocku należy uznać dyplom z 11 lipca 1275 roku ${ }^{11}$, w którym jednak miejscowość parafialna Stróża nie występuje ${ }^{12}$. Zdając sobie sprawę z zastrzeżeń co do wartości omawianego źródła, H. Grocholski próbuje jednak uwiarygodnić

${ }^{6}$ Myśliński, Początki miasta Kraśnika, s. 21.

7 Tamże, s. 20-21.

${ }^{8}$ Tamże, s. 20.

${ }^{9}$ M. Niwiński, Opactwo cystersów w Wachocku. Fundacja i dzieje uposażenia do końca wieków średnich, Kraków 1930, w: Rozprawy Polskiej Akademii Umiejętności. Wydziat HistorycznoFilozoficzny, seria 2, t. 43, nr 1, Kraków 1932, s. 158-163.

${ }_{10}$ Tamże, s. 161.

${ }^{11}$ Kodeks dyplomatyczny Małopolski (dalej: KDM), t. 2, nr 481, s. 135-138.

${ }^{12}$ Niwiński, Opactwo cystersów, s. $13 \mathrm{nn}$. 
jego treść, doszukując się w nim prawdziwej tradycji ${ }^{13}$, co jest możliwe nawet w przypadku dokumentów sfałszowanych. Na niekorzyść opinii Grocholskiego przemawia jednak zapis nazwy miejscowości w rzekomym dokumencie Bolesława Wstydliwego identyfikowanej jako Stróża. Otóż lekcja brzmi: „de Strozy”"14. Zauważamy, że nazwy miejscowości w tym dokumencie pisane są, co jest zresztą powszechną praktyką $\mathrm{w}$ średniowieczu, zawsze w sposób nieodmienny, w rzeczonym dokumencie, np. „de Lissow”, „,de Wanchock” etc. ${ }^{15}$ Nasza miejscowość nazywałaby się więc Strozy, a takiego zapisu nie znaleźliśmy w odniesieniu do Stróży w żadnym średniowiecznym dokumencie. Zwykle jej nazwę zapisywano: Stroza, Strocza, Strzosa, Sztroza, nawet Strzesza ${ }^{16}$, ale nie Strozy. Nie musimy nawet $\mathrm{w}$ tym miejscu mierzyć się z zadaniem identyfikacji tej miejscowości, a to choćby dlatego, że nie dysponujemy autentycznym dokumentem, który by nas do tego zmuszał. Warto jedynie powiedzieć, że jednak może chodzić tu o wieś Stróżyska, a w dokumencie mamy do czynienia ze źle odczytaną abrewiaturą lub tekst został w ciągu wieków zniekształcony ${ }^{17}$. Należy ponadto zaznaczyć, że wspomniany historyk zapewne myli się twierdząc, choć nie kategorycznie: „Zdaje się, że nie ma w Małopolsce żadnej innej wsi kościelnej mogącej tu wchodzić w rachubę"18. Istnieje bowiem dokument Kazimierza Wielkiego z 2 lutego 1348 roku nadający niejakiemu „nobili Pribconi” wieś Stara Stróża, leżącą nad rzeką Rabą przy ujściu do niej rzeki Trzebunii (oryg. Strzebunii) ${ }^{19}$. Lokalizacja tej wsi wskazuje, że w XIII wieku i później leżała ona w Ziemi Krakowskiej, a więc mógł nią dysponować Bolesław Wstydliwy, i nie musiała w jego czasach nosić przydomka „Stara”. Krótko mówiąc, argumentacja H. Grocholskiego, oparta o nieautentyczny dokument, nie ma siły przekonującej i można od niej odstąpić.

Inaczej ma się rzecz ze spisami świętopietrza. Są to bowiem oficjalne rejestry sporządzane przez kolektorów pobierających daninę na rzecz Stolicy Apostolskiej. W księgach kolektorów Stróża występuje wśród parafii archidiakonatu zawichojskiego. Zgodnie z przyjętym w źródle schematem zapiski dotyczące poszczególnych parafii są skonstruowane w następujący sposób: „plebanus ecclesiae de...”, ,parrochia ecclesiae de...”, ,ecclesia de...” lub „rector de...”, co dotyczy również Stróży. Dwukrotnie jest mowa o Jakubie, plebanie kościoła ze Stróży ${ }^{20}$. Można z tego wysnuć wniosek, że rejestry kolektorskie bez wątpienia świadczą o przynależności Stróży do grupy miejscowości parafialnych archidiakonatu za-

13 Grocholski, Wokół początków, s. 28-29. Później historyk ten stwierdzi kategorycznie, że „Ostatnim kościołem istniejącym niewątpliwie w XIII w. jest kościół w Stróży” (Powstanie archidiakonatu zawichojskiego, s. 161).

14 Niwiński, Opactwo cystersów, s. 161.

15 Tamże.

16 Zestawienie zapisów nazwy wsi Stróża, zob. Dzieje Lubelszczyzny, t. 3, s. 224.

${ }^{17} \mathrm{Na}$ temat wsi Stróżyska zob. Grocholski, Wokół początków, s. 29, przyp. 6.

${ }_{18}$ Grocholski, Wokół początków, s. 29.

19 KDM, t. 1, nr 225, s. 268-269.

20 Rejestry z XIV wieku zostały wydane przez J. Ptaśnika w Monumenta Poloniae Vaticana, t. 1-2, Kraków 1913. Wiadomości o Stróży pojawiają się dziewięciokrotnie: t. 1, s. 160, 235, 312, 398 , t. 2, s. $177,363,383,430,438$. Najstarsze rejestry opublikował również A. Theiner w Vetera Monumenta Poloniae et Lithuaniae, t. 1, Roma 1860, nr. 358-362, s. 228-287 (wiadomości o Stróży s. 256,279$)$. 
wichojskiego. Czy jednak jest to wniosek kategoryczny i niepodważalny? By odpowiedzieć na to pytanie należy najpierw spojrzeć na sytuację społeczną, gospodarczą i demograficzną okolic Stróży.

Wieś ta leży w pobliżu Kraśnika, który, jak wystarczająco uzasadnił to K. Myśliński, znajdował się przy starym szlaku handlowym wiodącym w kierunku Rusi ${ }^{21}$. Źródła polskie i Ruskie potwierdzają, że tym szlakiem z Lublina w kierunku Zawichostu, a dalej Sandomierza i Krakowa szły również najazdy ruskie, litewskie i tatarskie. Jedna z ważniejszych wypraw ruskich do ziem polskich miała miejsce w 1205 roku. Po oblężeniu Lublina, trasą przez Kraśnik wojowie księcia Romana ruszyli pod Zawichost, gdzie doszło do słynnej bitwy z rycerstwem Leszka Białego i Konrada Mazowieckiego. W 1243 roku Ziemię Sandomierską najechali książęta Daniel i Wasylko. Później, w związku z rywalizacją Konrada Mazowieckiego z Bolesławem Wstydliwym, doszło do dwóch najazdów książąt ruskich na Ziemię Sandomierską. Pierwszy w 1243 roku, zdaniem Z. Szambelana, miał charakter rabunkowy i był zakrojony na dużą skalę. Nas oczywiście najbardziej interesuje akcja księcia Daniela przebiegająca wzdłuż drogi Lublin - Zawichost, na której leżał Kraśnik. Drugi, z wiosny 1244 roku, również był związany ze wsparciem jakiego książęta Daniel i Wasylko udzielili Konradowi Mazowieckiemu - wtedy wojska ruskie spustoszyły ziemię sandomierską aż po Wisłę i $\operatorname{San}^{22}$. Najazdy ruskie i litewskie zdarzały się i później, ale ich zasięg pozostaje mniejszy i trudno ustalić, czy ich łupem padały okolice Kraśnika. Długosz informuje o spustoszeniu ziemi lubelskiej przez Litwinów w roku 1273, przez Jaćwingów w roku 1282 przedstawiając ogrom zniszczenia ${ }^{23}$.

Niszczycielskie były także najazdy tatarskie. Pierwszy z nich, obszernie opisany przez Długosza, dotknął także ziemię lubelską, a jego łupem padły Lublin i Zawichost ${ }^{24}$, a więc droga wiodła szlakiem przez Kraśnik. Dwa następne z lat 1259-1260 i 1287-1288 podążające zapewne to samą drogą co pierwszy również dosięgły okolic Kraśnika. Zarówno Długosz, jak kroniki ruskie wskazują na ogrom dokonanych zniszczeń przy pomocy ognia i miecza ${ }^{25}$. Wiek XIII i XIV to również najazdy Litwinów na ziemie polskie. Niektóre z nich musiały dosięgnąć ziemię lubelską.

Na skalę zniszczeń na Lubelszczyźnie, która stała się wręcz opustoszała, wskazuje przywilej biskupa krakowskiego Bodzanty z 14 lipca 1359 roku, wydany za wstawiennictwem króla Kazimierza Wielkiego, zwalniający jej mieszkańców z należnych biskupstwu krakowskiemu dziesięcin na okres 30 lat $^{26}$.

${ }^{21}$ Myśliński, Początki miasta Kraśnika, s. 14 nn.

${ }_{22}$ Z. Szambelan, Najazdy ruskie na Ziemię Sandomierska $w$ XIII wieku, „Acta Universitatis Lodzienzis. Folia Historica", 36 (1989) s. 13-14, 16-17.

${ }_{23}$ Jana Dlugosza Roczniki czyli kroniki sławnego Królestwa Polskiego, ks. 7-8, Warszawa 1974 , s. 232-233, $276 \mathrm{nn}$.

${ }^{24}$ Tamże, s. 10. G. Labuda uznaje obecność Tatarów na Lubelszczyźnie w zasadzie za pewne (Wojna z Tatarami w roku 1241, „Przegląd Historyczny”, 50 (1959) nr 2, s. 204).

${ }_{25}$ Jana Dlugosza Roczniki, ks. 7-8, s. 155 nn, 313 nn; Ипатіевская льтопись, w: Полное собраніе русскихъ льтописей, т. 2, Санктпетербургъ 1843, s. 347.

${ }^{26}, \ldots .$. quod terre Lublinensis, Seczechouiensis et Lucouiensis nostre dyocesis, per insultum infidelium Tartharorum et Litwanorum peccatis exigentibus sunt plurimum desolate, uolentesque, vt ad 
W takiej sytuacji można by przyjąć, że Stróża, leżąca nieco na uboczu szlaku handlowego i trasy przemarszów wrogiego rycerstwa, stała się nie siedzibą parafii, lecz plebana, który chronił się w miejscu pełniącym funkcje obronne, na co wskazuje sama nazwa naszej wsi, bowiem za właściwą siedzibę parafii trzeba uznać miejscowość, w której znajdował się kościół będący ośrodkiem życia religijnego. Jeśli założymy, że w Stróży nie było kościoła, a jedynie mogła być siedzibą proboszcza, prawdopodobnie tymczasową, to nie sposób uznać ją za wieś parafialną. W takim przypadku mogła uchodzić za wieś parafialną zwłaszcza w oczach kolektora denara św. Piotra, odbierającego tam właśnie należną Stolicy Apostolskiej daninę.

Oczywiście takie wyjaśnienie samo w sobie jeszcze nie ma siły przekonującej i bez innych przesłanek można by umieścić je wśród zbyt daleko idących domysłów i mrzonek, dlatego musimy poszukać argumentów potwierdzających nasze przypuszczenia.

Z pomocą przychodzi nam jeden z najważniejszych dokumentów do poznania średniowiecznych dziejów Kraśnika. Mamy na myśli dyplom Ludwika Węgierskiego z 26 lipca 1377 roku, którym nadaje Dymitrowi z Goraja i jego bratu Iwanowi zamek Goraj i miasto Kraśnik z przyległymi wsiami. Dokument ten jest przedmiotem dyskusji w kwestii jego znaczenia, mianowicie czy jest on aktem fundacyjnym Kraśnika na prawie niemieckim, czy przenosi Kraśnik z prawa polskiego na niemieckie, czy wreszcie potwierdza wcześniej już posiadane prawo niemieckie przez Kraśnik, teraz jedynie przypomniane w związku z przekazaniem miasta nowym właścicielom? Problem ten jest niewątpliwie ważny, ale jednocześnie trudny do jednoznacznego rozstrzygnięcia. K. Myśliński stoi na stanowisku przeniesienia Kraśnika z prawa polskiego na niemieckie przez Ludwika Węgierskiego o czym ma świadczyć nazwanie Kraśnika miastem: civitas sive oppidum $^{27}$. Innego zdania jest H. Grocholski, który uważa, że sformułowania użyte w rzeczonym dokumencie świadczą o istnieniu w Kraśniku urządzeń prawnych właściwych dla prawa niemieckiego ${ }^{28}$. Kiedy jednak ta lokacja miałaby nastąpić - nie sposób ustalić.

Tymczasem chcemy zwrócić uwagę na fragment dokumentu, którego znaczenia dotychczas nie doceniono. Chodzi o ustęp określający przedmiot nadania dla braci Dymitra i Iwana. Przytoczmy go w całości.

...castrum nostrum dictum Goray (...) necnon ciuitatem siue opidum Crasznik nuncupatum, cum villis inferius denotatis, videlicet Sztroza, Wyrznicza et dimidia villa dicta Rzeczicza, ac laneis vniuersis ad ipsas pertinentibus, cum omnibus et singulis iuribus, dominijs, fructibus, redditibus, censibus, agris, pratis, siluis, nemoribus, virgultis, rubetis, quercetis, molendinis, piscinis, la-

possidendum easdem populus Cristianus feruencius inuitetur, ad peticionem instantem serenissimi principis et domini nostri, domini Kasimiri Dei gracia regis Polonie illustris, de voluntate et consensu fratrum nostrorum, capituli scilicet Cracouiensis, omnibus et singulis, qui in terris predictis se locauerint aut actenus sunt locati in villis, predijs et possessionibus, in quibus ad mensam nostram episcopalem decime pertinebant, a solucione decime triginta annorum spacio a data presencium plenam et omnimodam concedimus libertatem..." (KDM, t. 3, nr 730, s. 127-128).

${ }^{27}$ Myśliński, Początki miasta Kraśnika, s. 22

${ }^{28}$ Grocholski, Wokót początków, s. 30. 
cubus, mellificijs, venacionibus, aquis earumque decursibus ac alijs vtilitatibus vniuersis, quibuscumque vocitentur nominibus, que nunc ibidem existunt et (im)posterum poterint suboriri, situatum et situata in terra Sandomiriensi, prout dicta castrum et ciuitas cum predictis villis ipsis adiacentibus in eorum grenicijs et metis circumferencialiter sunt distincta, et prout ipsum et ipsa cum villis superius expressatis nos et nostri illustres predecessores, reges Polonie tenuimus hucusque et possedimus, damus, ascribimus, incorporamus, adiungimus donacione inuiolabili et donamus ipsum castrum et ciuitatem cum villis prenotatis tenendum, habendum, donandum, alienandum, vendendum, commutandum, in vsus eorum beneplacitos conuertendum, et per memoratos Dymitrum et Ywanum eorumque heredes et successores legittimos, ut predicitur, vtriusque sexus temporibus perpetuis pacifice possidendum: constituentes memoratos Dymitrium et Ywanum eorumque heredes et successores legittimos vtriusque sexus prefati castri dicti Goray alias Lade et ciuitatis Crasnik et villarum omnium ad ipsum et ad ipsa pertinencium quomodolibet, dominos veros et legittimos possessores ${ }^{29}$.

Z przytoczonego fragmentu wynika bezspornie, że Kraśnik i wymienione obok niego wsie: Stróża, Wyżnica i Rzeczyca do chwili wystawienia powyższego dokumentu należały do Ludwika Węgierskiego i jego poprzedników królów Polski, były więc miejscowościami królewskimi (nos et nostri illustres predecessores, reges Polonie tenuimus hucusque et possedimus). Przez prawowitego właściciela zostały nadane Gorajskim (damus, ascribimus, incorporamus, adiungimus donacione inuiolabili et donamus). Dalej król szczegółowo określa przedmiot nadania. Od razu zauważamy, że nawet słowem nie wspomniano o funkcjonowaniu kościoła ani w Kraśniku, ani w Stróży. Niczego też nie można wywnioskować z treści dokumentu o istnieniu jakiegokolwiek uposażenia takich kościołów. Była to jednak sprawa na tyle poważna, iż trudno sobie wyobrazić, by król ją pominął milczeniem. Jeśli w Stróży, bądź w Kraśniku, istniał kościół, to rodzi się ponadto pytanie: do kogo należał jego patronat lub czyją był własnością? Trudno przypuszczać, że patronat kościoła w mieście lub wsi królewskiej nie należał do króla. Przekazanie patronatu kościoła niewątpliwie było istotniejsze od przekazania lasu, łąki, stawu, barci etc. i król powinien o tym wspomnieć. Jeżeli zaś chciałby patronat zatrzymać dla siebie lub przynależał on jeszcze komuś innemu, należało poczynić takie zastrzeżenie, aby uniknąć wszelkich nieporozumień. Uważamy zatem, że omawiany dokument przeczy tezie o istnieniu kościoła w Kraśniku, a tym bardziej w Stróży, która stała się dobrem dodatkowym przy głównym nadaniu, jakim były zamek Goraj i miasto Kraśnik. Podważa także wiarygodność danych zawartych w czternastowiecznych spisach świętopietrza na temat domniemanego ulokowania w Stróży parafii i kościoła. Tym sposobem nasze przypuszczenia co do roli Stróży stanowiącej raczej miejsce rezydencji i dającej być może schronienie plebanowi, a nie będącej siedzibą parafii, nabierają wiarygodności lub przynajmniej zmuszają do brania takiej ewentualności pod uwagę.

Oczywiście mógłby ktoś twierdzić, że w wieku XIV istniała parafia w Stróży, a po fundacji Kraśnika przestała być potrzebna. W takim przypadku powsta-

${ }^{29} \mathrm{KDM}$, t. 3, nr 893, s. 310-311. 
je pytanie, co się tak naprawdę z nią stało? Jej zniknięcie musiałoby nastąpić bardzo gwałtownie. T. Gromnicki, podając zestawienia wpływów świętopietrza z poszczególnych parafii, wymienia parafię w Stróży (Strzoza) po raz ostatni w $1374 \mathrm{roku}^{30}$. Zaledwie trzy lata później w źródłach wszelki ślad po niej ginie, w tym w dyplomie króla Ludwika Węgierskiego, co jest, jak już zaznaczyliśmy, szczególnie dziwne i wręcz niewythumaczalne. Ponadto parafia w Stróży nie jest wzmiankowana w żadnych średniowiecznych dokumentach, łącznie z Liber beneficiorum Jana Długosza, poza oczywiście przywoływanymi już wielokrotnie rejestrami daniny na rzecz Stolicy Apostolskiej. Jedyny wniosek jaki się nasuwa, jest taki, że w średniowieczu parafii w Stróży po prostu nie było.

Gdzie zatem szukać ośrodka parafialnego, który by obejmował swym zasięgiem rejon Kraśnika?

Najpierw naszą uwagę przyciąga sam Kraśnik. Żadne jednak źródło średniowieczne sprzed XV wieku nie wspomina o istnieniu kościoła w Kraśniku. Dotyczy to także uznanych za sfałszowane dokumentów:

- Władysława Łokietka z 10 lutego 1290 roku wydanym dla Krystyna z Goraja, w którym jest mowa o zwolnieniu ziemi lubelskiej z ciężarów państwowych i kościelnych na 30 lat z powodu zniszczeń spowodowanych przez Tatarów i nadaniu Kraśnikowi prawa pobierania cła ${ }^{31}$;

— Kazimierza Wielkiego z 26 czerwca 1356 roku potwierdzającego przywilej jego ojca dla wspomnianego Krystyna ${ }^{32}$.

W pierwszym z wymienionych dokumentów Kraśnik jest nazwany miastem (oppidum) i miał w nim stać zamek lub twierdza (castrum). Nie można wykluczyć, że źródła te przekazały tradycję o miejskiej przeszłości Kraśnika sięgającej XIII wieku. Konsekwencją posiadania przez Kraśnik statusu miejskiego, targowego byłoby istnienie tu kościoła, również już w XIII wieku ${ }^{33}$. Taką opinię prezentuje K. Myśliński i do jej weryfikacji teraz powracamy. Trzon argumentacji Myślińskiego zasadza się na założeniu, że w osadach tego typu zwykle lokowano kościoły oraz na analizie zapisów dotyczących Kraśnika w Liber beneficiorum Jana Długosza, chodzi przede wszystkim o notatkę na temat dziesięciny przynależnej cystersom z Koprzywnicy pobieranej ze wsi Sulów, która nota bene dawała także część dochodów dla kościoła w Kraśniku: „Item scoltetia est ibi, habens quatuor cum medio laneos, de quorum duobus, qui erant antiqui, solvit decimam manipularem ecclesiae in Krasznik, de duobus vero cum medio, qui ex cruda radice, solvit decimam manipularem monasterio Koprzywniczensis" ${ }^{34}$. Biorąc pod uwagę fakt objęcia w posiadanie tej wsi przez cystersów z Koprzywnicy w połowie XIII wieku oraz informacje pochodzące od Długosza o pobieraniu przez klasztor kanoników regularnych w Kraśniku dziesięciny z dawnych gruntów (qui erant antiqui)

${ }^{30}$ T. Gromnicki, Świętopietrze w Polsce, Kraków 1908, s. 388-389.

${ }^{31} \mathrm{KDM}$, t. 2, nr 615, s. 287-288.

${ }^{32}$ KDM, t. 3, nr 960, s. 376-378.

${ }^{33}$ Myśliński, Początki miasta Kraśnika, s. 18-19.

34 Joannis Dlugosz Senioris canonici cracoviensis Liber beneficiorum dioecesis cracoviensis (dalej: LB), t. 3, w: Joannis Dlugosz Senioris canonici cracoviensis Opera omnia, wyd. A. Przezdziecki, t. 9, Kraków 1864, s. 397. 
sołectwa sulowskiego, a przez cystersów koprzywnickich z gruntów nowo wykarczowanych (ex cruda radice), Myśliński wyciąga wniosek, że kościół w Kraśniku istniał i pobierał swoją daninę ze wspomnianych dóbr jeszcze przed nabyciem Sulowa przez cystersów, a więc już w XIII wieku; gdyby chronologia była inna, to cystersi powinni korzystać z dawnych gruntów, a kościół w Kraśniku z nowych. Rozumowanie K. Myślińskiego jest ciekawe, ale nie do utrzymania wobec świadectw innych źródeł. Dokument Władysława Jagiełły z 22 lipca 1400 roku świadczy o przejęciu przez króla na własność wsi Sulów i Zakrzów, a to z powodu ich ruiny i ubóstwa ludności tam zamieszkującej oraz dla przywrócenia im dobrej kondycji gospodarczej ${ }^{35}$. To właśnie z okresu kurateli króla na tymi wsiami może pochodzić prawo kanoników regularnych z Kraśnika do dziesięciny z dawnych gruntów sołectwa w Sulowie. Spór o te m.in. dobra między biskupstwem krakowskim a cystersami był przedmiotem wyroku sądu z 1466 roku, w którym cystersom przyznano prawo do pobierania dochodu właśnie z nowych gruntów ${ }^{36}$. Długosz miał zatem prawo podać cytowane powyżej informacje. Ponadto dokument fundacyjny wystawiony przez Jana Rabsztyńskiego dla klasztoru kanoników regularnych w Kraśniku zawiera wzmiankę o dawniej już zawartej ugodzie pomiędzy opatem koprzywnickim a plebanem kraśnickim w sprawie pobierania dochodów z pól sołeckich w Sulowie i Zakrzowie ${ }^{37}$. W związku z tym wywód K. Myślińskiego na temat trzynastowiecznego rodowodu kościoła w Kraśniku traci na znaczeniu. Pozostają jedynie poszlaki oparte na przekonaniu, że w osadach targowych lub miastach powinien był istnieć kościół.

Pierwsza pewna wzmianka o istniejącym w Kraśniku kościele pochodzi dopiero z 1403 roku, z dokumentu wystawionego przez Władysława Jagiełłę, potwierdzającego nadanie wsi Rzeczyca kościołowi parafialnemu w Kraśniku przez Beatę, wdowę po Dymitrze z Goraja. Z treści dokumentu wynika, że Beata z Bożegodaru wykonała $w$ ten sposób testament swego męża ${ }^{38}$. Kościół nosił wezwanie św. Pawła. Uważamy, że mógł go fundować Dymitr z Goraja i to niedługo przed swoją śmiercią, który jednak nie doprowadził wszakże sprawy do końca, co zdaje się potwierdzać fakt uposażania go lub doposażenia przez Beatę zgodnie $\mathrm{z}$ wolą męża. W świetle wyników przeprowadzonych niedawno badań obecnej świątyni kraśnickiej okazuje się, że najstarsza część kościoła, dzisiejsze prezbiterium, została wzniesiona w I połowie XV wieku (przed rokiem 1448), a wcześniej, w pczątkach XV wieku, na tym miejscu stał kościół drewniany ${ }^{39}$. Możemy domniemywać, że był to właśnie kościół pw. św. Pawła, prawdopodobnie fundacji

\footnotetext{
${ }^{35}$ Biblioteka Książąt Czartoryskich, perg. 259.

${ }^{36}$ Item in recompensam favoris et benivolentie $[s]$ quam prefatus reverendissimus in Christo pater dominus Johannes Dei gratia episcopus cum sue venerabilis capitulo cracoviensis favedo graciose prefatas decimas nowalium prefatis dominis abbati et conventu de Coprzywnycza exhibuit et ostendit, obiudicamus prefato — - episcopo et suis successoribus decimam paccuniariam quatuor marcorum communis peccuniae in oppido Strzeschow (Biblioteka Książąt Czartoryskich, perg. 561).

${ }^{37}$ W. Bielak, Dokument fundacyjny klasztoru Kanoników Regularnych Laterańskich w Kraśni$k u$, „Archiwa Biblioteki i Muzea Kościelne”, 107 (2017) s. 28-29.

${ }^{38} \mathrm{KDM}$, t. 4, nr 1077, s. 87-88.

${ }^{39}$ B. Stolarz, Prace konserwatorskie i badawcze w obrębie prezbiterium kościoła pw. Wniebo-
} 
Dymitra z Goraja. Po przejęciu Kraśnika przez Andrzeja Tęczyńskiego, co nastąpiło wskutek jego małżeństwa z Anną, córką Dymitra z Goraja, został on rozebrany i w tym miejscu rozpoczęto bydowę świątyni murowanej, już dedykowanej Najświętszej Marii Pannie. Likwidacja starego kościoł i wzniesienie nowego było też okazją do zmiany wezwania kościoła. Można więc przyjąć, że kościół parafialny w Kraśniku powstał dopiero w końcu XIV wieku.

Inną możliwość w poszukiwaniu ośrodka kościelnego daje wieś Grambienica. Jan Długosz pisze o niej w Liber beneficiorum trzykrotnie, w dwóch miejscach określając ją jako parafię. Jest to świadectwo ważne i musimy uznać je za pewne - można bowiem zarzucić dziełu Długosza niekompletność rejestru parafii w XV wieku lub niedokładności przy podawaniu uposażenia poszczególnych instytucji kościelnych $^{40}$, ale nie sposób posądzać go o zmyślanie parafii fikcyjnych. Najistotniejsze dla nas wiadomości kronikarz podaje w tomie trzecim:

Item in prefata villa Grambyenicza fuit quondam ecclesia parochialis lignea, Sanctae Mariae Virgini dicta, et milites residebant in ea habentes curias speciales, et agros praediales. Postquam vero inde haereditatibus venditis, fecerunt discessum, et villa ipsa Grambyenicza oppido Crasznik fuit adiuncta, etiam ecclesia in Grambyenicza ecclesiae de Krasznik fuit et est cum suis proventibus unita ${ }^{41}$.

Z powyższego wynika, że Grambienica była wsią parafialną z kościołem dedykowanym Najświętszej Marii Pannie. Zanim została sprzedana, mieszkali tam rycerze (milites) w dworach zapewne warownych (curias speciales). Na temat czasu sprzedaży i osoby nabywcy Długosz milczy. Ponieważ nie wspomina o niej przywoływany już dokument Ludwika Węgierskiego z 1377 roku można by przypuszczać, że wtedy jeszcze była własnością rycerską. Kupiłby ją więc Dymitr z Goraja, bowiem występuje ona jako scheda po nim i przechodzi na własność jego córek, co potwierdza akt podziału jego dóbr w 1405 roku ${ }^{42}$. W tym samym czasie miało dojść, według Długosza, do połączenia parafii grambinickiej i kraśnickiej. Wydaje się, że kupno wsi i połączenie parafii nastąpiło już po powstaniu kościoła św. Pawła w Kraśniku, bo w innym razie po co Dymitr, mając przecież w rękach kościół parafialny, budowałby nowy i przeznaczał dla niego uposażenie, które, jak wspomnieliśmy, sfinalizowała jego żona w 1403 roku. Nie jest to oczywiście warunek konieczny, gdyż równie dobrze właściciel Kraśnika mógł chcieć zaznaczyć swą bytność w nowo uzyskanych dobrach, tworząc własny ośrodek kościelny i urządzając miasto zgodnie ze swoją wolą i wizją. Do połączenia parafii mogło też dojść później, gdy Andrzej Tęczyński rozpoczął budowę świątymi

wzięcia Najświętszej Marii Panny w Kraśniku, „Wiadomości Konserwatorskie Województwa Lubelskiego", 19 (2017) s. 314.

40 Ostatnio na temat krytyki Liber beneficiorum: L. Poniewozik, Obraz parafii małopolskich $w$ świetle liber beneficiorum Jana Dlugosza. Luki i wybrane mośliwości uzupetnienia, „Archiwa Biblioteki i Muzea Kościelne”, 108 (2017) s. 237-267.

${ }^{41}$ LB, t. 3, s. 176. O parafii Gambinica również LB, t. 2, s. 501: „fuit ibi quondam ecclesia parochialis Snctae Mariae dicta, sed unita est ecclesiae in Krasznik".

${ }_{42}$ Starodawne prawa polskiego pomniki, wyd. A. Z. Helcel, t. 2, Kraków 1870, nr 1093, s. $162-163$. 
murowanej i stary kościół w Grambienicy definitywnie przestał być potrzebny. Ta ostatnia możliwość wydaje się najpewniejsza. Skutkiem bowiem takiego połączenia byłoby przejęcie przez kościół Tęczyńskich wezwania kościoła grambienickiego, czyli Najświętszej Marii Panny, co w przypadku fuzji parafii i rozbiórki drewnianego kościoła w Kraśniku stanowi logiczną konsekwencję. Na taką ewentualność wskazuje też charakterystyczny zwrot użyty przez Jana Długosza: „fuit et est (...) unita”, który naszym zdaniem świadczy o jakiejś równoprawności obu parafii w procesie ich łączenia, która pozostawiła ślad jeszcze w czasach Długosza, to znaczy parafia w Grambienicy nie została po prostu zlikwidowana lub porzucona, a jej terytorium i uposażenie wcielone do parafii w Kraśniku, ale uszanowano tradycję starszej parafii, nadając np. wezwanie jej kościoła, kościołowi kraśnickiemu. Takiego uzasadnienia roli dziejowej rzekomej parafii w Stróży nie daje żadne źródło. Jan Długosz więc wprost przeczy opiniom historyków chcących widzieć taki proces w połączeniu Kraśnika i Stróży ${ }^{43}$.

W tym miejscu warto wspomnieć o lokalizacji Grambienicy: jedną propozycję zaprezentowł Stefan Wojciechowski, drugą zamieszczono w czwartym tomie Dziejów Lubelszczyzny. Obie opierają się na założeniu, że dzisiejsza wieś Pasieka, położona w pobliżu Kraśnika, jest zaginioną wsią Bieliny wchodzącą w średniowieczu wskład dóbr parafii kraśnickiej, a interesująca nas Grambienica leżała między Pasieką a Kraśnikiem. Różnica między przedstawionymi opiniami polega w zasadzie na umiejscowieniu Grambienicy na lewym bądź na prawym brzegu rzeki Wyżnianki ${ }^{44}$. Identyfikacja Bielin z Pasieką może jednak okazać się błędna. Na marginesie dokumentu fundacyjnego klasztoru kanoników regularnych wystawionym na przez Jana Rabsztyńskiego znajduje się następujaca późniejsza glosa: „Pasieczna Wola modo vulgo vocatur Pasieka”45. Ta notatka mogła powstać tylko w czasach, gdy funkcjonowała oficjalna nazwa tej wsi - Pasieczna Wola, a zaczęła upowszechniać się nazwa Pasieka. Według tego świadectwa Pasiekę należałoby wiązać raczej z Pasieczną Wolą. W takim wypadku Bieliny leżałyby w miejscu, gdzie starano się umiejscowić Grambienicę, a Grambienicę przesunąć na północny zachód od centrum dzisiejszego Kraśnika. Biorąc pod uwagę informację zawartą w Liber beneficiorum na temat zamieszkiwania Grambienicy przez milites skłaniamy się ku twierdzeniu, że była ona położona bliżej zamku kraśnickiego i razem z nim stanowiła punkt obrony miasta. Wskazują na taką możliwość inne dane źródłowe. W 1592 roku wizytator archidiakonatu zawichojskiego zapisał w protokole informację o istnieniu w Kraśniku, w okolicach zamku, dawnego kościoła pw. Wniebowzięcia NMP ${ }^{46}$. Również inwentarz miasta Kraśnika pocho-

${ }^{43} \mathrm{~Np}$. „Kiedy w zjednoczonym państwie Łokietka i Kazimierza Wielkiego funkcje obronne Stróży zaczęły szybko zanikać, tutejszy kościół parafialny podupadł (...). Wnet potem nastąpiło formalne przeniesienie siedziby parafii do Kraśnika" (Myśliński, Początki miasta Kraśnika, s. 21).

${ }^{44}$ S. Wojciechowski, Zaginione osady w Lubelskiem, „Pamiętnik Lubelski”, 1 (1930) s. 131132, 143; Dzieje Lubelszczyzny, red. T. Mencel i in., t. 4 : Osady zaginione i o zmienionych nazwach historycznego województwa lubelskiego, oprac. S. Wojciechowski, A. Sochacka, R. Szczygieł, Warszawa 1986, s. 56-57, 102-103.

${ }^{45}$ Archiwum Narodowe w Krakowie, perg. 887.

${ }^{46}$ „In eodem oppido, in area castri est ecclesia lignea veteris aedificationis tituli Assumptionis Gloriosae Virginis Mariae (Archiwum Kurii Metropolitalnej w Krakowie, sygn. AV 1, k. 36v 
dzący z 1612 roku wspomina jeszcze o tym kosciele, a K. Myśliński widzi w nim pozostałości pierwotnej świątyni kraśniciej ${ }^{47}$. Jak zauważamy wezwanie kościoła stojącego do XVII wieku ,in area castri” zgadza się dokładnie z wezwaniem kościoła obecnego. Gdy przyjąć, iż nie była to jednak świątynia grambienicka, to jej istnienie w tym miejscu, w oparciu o dostępne źródła, byłoby niewytłumaczalne.

Podsumowując powyższe rozważania, zauważamy, że istnienie parafii i kościoła w Stróży w XIV wieku jest bardzo słabo udokumentowane, a wręcz niektóre źródła przeczą takiej możliwości, nie zachowała się też żadna tradycja o przeszłości kościelnej tej wsi. W związku z tym funkcjonowanie parafii w Stróży jest bardzo mało prawdopodobne. Do czasu wskazania śladów archeologicznych po czternasowiecznym kościele w Stróży, opinię tę należy porzucić. Twierdzimy ponadto, że to parafia w Grambienicy (a nie w Stróży) stanowiła pierwotne zaplecze kościelne zespołu osadniczego w Kraśniku, co z czasem, gdy wzrosło znaczenie Kraśnika, skutkowało połączeniem tych dwu parafii w jedną.

\section{BIBLIOGRAFIA}

\section{Źródla}

Archiwum Kurii Metropolitalnej w Krakowie, sygn. AV 1.

Biblioteka Książąt Cartoryskich, perg. 259, perg. 561.

Jana Dtugosza Roczniki czyli Kroniki Stawnego Królestwa Polskiego, ks. 7-8, Warszawa 1974.

Joannis Dlugosz Senioris canonici cracoviensis Liber beneficiorum dioecesis cracoviensis, t. 1-3, w: Joannis Dlugosz Senioris canonici cracoviensis Opera omnia, wyd. A. Przezdziecki, t. 7-9, Kraków 1863-1864.

Kodeks dyplomatyczny Małopolski, wyd. F. Piekosiński, Kraków 1876-1905, t. 1: nr 225 , s. 268-269, nr 481, s. 135-138; t. 2: nr 615, s. 287-288; t. 3: nr 730, s. 127-128, nr 893, s. $310-311$, nr 960, s. 376-378; t. 4, nr 1077, s. 87-88.

Starodawne prawa polskiego pomniki, wyd. A. Z. Helcel, t. 2, Kraków 1870, nr 1093, s. $162-163$.

Vetera monumenta Poloniae et Lithuaniae, wyd. A. Thainer, t. 1, Roma 1860.

\section{Opracowania}

Bielak W., Dokument fundacyjny klasztoru Kanoników Regularnych Laterańskich w Kraśniku, „Archiwa Biblioteki i Muzea Kościelne”, 107 (2017) s. 26-30.

Dzieje Lubelszczyzny, red. T. Mencel i in., t. 3: Stownik historyczno-geograficzny województwa lubelskiego w średniowieczu, oprac. S. Kuraś, Lublin 1983.

Dzieje Lubelszczyzny, red. T. Mencel i in., t. 4 : Osady zaginione i o zmienionych nazwach historycznego województwa lubelskiego, oprac. S. Wojciechowski, A. Sochacka, R. Szczygieł, Warszawa 1986.

(Ośrodek Archiwów, Bibliotek i Muzeów Kościelnych, mikrofilm sygn. 3275), Grocholski, Wokót poczatków, s. 32.

${ }^{47}$ Myśliński, Początki miasta Kraśnika, s. 19-20. 
Gołub S., Kościót pw. Wniebowzięcia Najświętszej Marii Panny w Kraśniku - wyniki badań archeologicznych, w: Kościoły, cerkwie i klasztory Lubelszczyzny w świetle badań archeologicznych, red. E. Banasiewicz-Szykuła, Lublin 2013, s. 11-34.

Grocholski H., Powstanie archidiakonatu zawichojskiego i jego najstarsze kościoły do połowy XIV w., „Roczniki Humanistyczne”, 13 (1965) z. 2, s. 151-162.

Grocholski H., Wokół początków Kraśnika, w: Z dziejów powiatu kraśnickiego, red. Z. Hirsz, Lublin 1963, s. 28-32.

Gromnicki T., Świętopietrze w Polsce, Kraków 1908.

Labuda G., Wojna z Tatarami w roku 1241, „Przegląd Historyczny”, 50 (1959) nr 2, s.

Landecka H., Kościót parafialny pod wezwaniem Najświętszej Marii Panny w Kraśniku - nowe ustalenia badawcze po I etapie badań - 2008-2009, „Budownictwo i Architektura", 7 (2010) s. 53-64.

Myśliński K., Dymitr z Goraja i poczatki Kraśnika, w: Problemy historii i archiwistyki, red. T. Mencel, Lublin 1986, s. 21-30.

Myśliński K., Początki miasta Kraśnika i Urzędowa na tle rozwoju południowej Lubelszczyzny, w: Z dziejów powiatu kraśnickiego, red. Z. Hirsz, Lublin 1963, s. 11-27.

Niwiński M., Opactwo cystersów w Wachocku. Fundacja i dzieje uposażenia do końca wieków średnich, Kraków 1930, w: Rozprawy Polskiej Akademii Umiejętności. Wydział Historyczno-Filozoficzny, seria 2, t. 43, nr 1, Kraków 1932, s. 1-164.

Poniewozik L., Obraz parafii małopolskich $w$ świetle liber beneficiorum Jana Długosza. Luki i wybrane mośliwości uzupetnienia, „Archiwa Biblioteki i Muzea Kościelne”, 108 (2017) s. 237-267.

Stolarz B., Prace konserwatorskie i badawcze w obrębie prezbiterium kościoła pw. Wniebowzięcia Najświętszej Marii Panny w Kraśniku, „Wiadomości Konserwatorskie Województwa Lubelskiego", 19 (2017) s. 313 nn.

Szambelan Z., Najazdy ruskie na Ziemię Sandomierska w XIII wieku, „Acta Universitatis Lodzienzis. Folia Historica", 36 (1989) s. 7-32.

Wojciechowski S., Zaginione osady $w$ Lubelskiem, w: Pamiętnik Lubelski, t. 1, Lublin 1930, s. 116-169.

Zielińska E., Kultura intelektualna kanoników regularnych z klasztoru w Kraśniku w latach 1469-1563, Lublin 2002.

\section{PROBLEM ISTNIENIA PARAFII W STRÓŻY W ARCHIDIAKONACIE ZAWICHOJSKIM W ŚREDNIOWIECZU}

\section{Streszczenie}

Artykuł stara się odpowiedzieć na pytanie czy można uznać bezwarunkowo za prawdziwe poglądy obecne w historiografi dawniejszej i współczesnej o istnieniu parafii w Stróży już w okresie średniowiecza. Ocenie poddano argumentację najważniejszych autorów, którzy do obiegu naukowego wprowadzili i upowszechnili tę opinię. $\mathrm{Na}$ podstawie analizy zachowanych źródeł starano się wykazać, że funkcjonowanie parafii w średniowiecznej Stróży jest wysoce problematyczne, a ośrodka kościelnego w okolicach Kraśnika należy raczej szukać w innych miejscowościach. Autor stoi na stanowisku, 
że takim ośrodkiem mógł być albo sam Kraśnik, albo położona w jego pobliżu wieś Grambienica, w której, według wiarygodnego świadectwa Jana Długosza, istniał w XIV wieku kościół parafialny.

Słowa kluczowe: Stróża; Kraśnik; Grambienica; Gorajscy; Tęczyńscy

\title{
A PROBLEM OF THE EXISTENCE OF THE PARISH IN STRÓŻA IN THE ARCHDEACONRY OF ZAWICHOST IN THE MIDDLE AGES
}

\begin{abstract}
Summary
The article aims to answer the question whether it is possible to state unconditionally, according to the views present in older and modern historiography, that the parish in Stóża existed as early as in the Middle Ages. The paper assesses the arguments of the most important authors who have introduced this view into the literature and contributed to its spreading. Analyzing the surviving sources, the author of the following article reveals that the functioning a parish in Stróża is highly problematic, and that a parish could exist in Kraśnik itself or in the nearby village of Grambienica, in which, by Jan Długosz's reliable account, a parish church existed in the 14th century.
\end{abstract}

Kewords: Stróża; Kraśnik; Grambienica; the Gorajski family; the Tęczyński family 